\title{
Glucocorticoid Metabolism in Obesity and Following Weight Loss
}

\section{OPEN ACCESS}

Edited by:

Alexander Kokkinos, National and Kapodistrian University

of Athens, Greece

Reviewed by:

Vaia Lambadiari,

University of Athens Medical School, Attikon Hospital, Greece

Gregory James Cooney, University of Sydney, Australia

*Correspondence:

Guy A. Rutter

g.rutter@imperial.ac.uk

Specialty section This article was submitted to

Obesity,

a section of the journal

Frontiers in Endocrinology

Received: 01 November 2019

Accepted: 30 January 2020

Published: 20 February 2020

Citation:

Akalestou $E$, Genser $L$ and Rutter GA (2020) Glucocorticoid Metabolism in Obesity and Following Weight Loss.

Front. Endocrinol. 11:59.

doi: 10.3389/fendo.2020.00059

\begin{abstract}
Elina Akalestou ${ }^{1}$, Laurent Genser ${ }^{1,2}$ and Guy A. Rutter ${ }^{1 *}$
${ }^{1}$ Section of Cell Biology and Functional Genomics, Division of Diabetes, Endocrinology and Metabolism, Department of Metabolism, Digestion and Reproduction, Imperial Centre for Translational and Experimental Medicine, Imperial College London, London, United Kingdom, ${ }^{2}$ Department of Digestive and Hepato-Pancreato-Biliary Surgery, Liver Transplantation, Assistance Publique-Hôpitaux de Paris, Pitié-Salpêtrière University Hospital, Institut Hospitalo-Universitaire ICAN, Sorbonne Université, Paris, France
\end{abstract}

Glucocorticoids are steroid hormones produced by the adrenal cortex and are essential for the maintenance of various metabolic and homeostatic functions. Their function is regulated at the tissue level by $11 \beta$-hydroxysteroid dehydrogenases and they signal through the glucocorticoid receptor, a ligand-dependent transcription factor. Clinical observations have linked excess glucocorticoid levels with profound metabolic disturbances of intermediate metabolism resulting in abdominal obesity, insulin resistance and dyslipidaemia. In this review, we discuss the physiological mechanisms of glucocorticoid secretion, regulation and function, and survey the metabolic consequences of excess glucocorticoid action resulting from elevated release and activation or up-regulated signaling. Finally, we summarize the reported impact of weight loss by diet, exercise, or bariatric surgery on circulating and tissue-specific glucocorticoid levels and examine the therapeutic possibility of reversing glucocorticoid-associated metabolic disorders.

Keywords: glucocorticoids, obesity, weight loss, bariatric surgery, 11 $\beta$-HSD1

\section{GLUCOCORTICOID SECRETION}

Glucocorticoid hormones are a class of corticosteroids, produced by the adrenal cortex primarily under the control of the hypothalamic-pituitary-adrenal (HPA) axis (1). Briefly, corticotropinreleasing hormone $(\mathrm{CRH})$ and vasopressin are released from the hypothalamus and synergistically stimulate the secretion of stored adrenocorticotropic hormone (ACTH) from corticotrope cells in the anterior pituitary gland. Following this, ACTH is transported by the blood to the adrenal cortex, where it rapidly stimulates biosynthesis of corticosteroids such as cortisol from cholesterol (2). However, it recently became apparent (3) that the fine-tuning and regulation of the adrenal system is also controlled by ACTH-independent mechanisms. These include a temporal lag between stimulus-induced changes in circulating ACTH and in corticosteroid levels (4), adrenal corticosteroid metabolism and kinetics, and plasma protein binding (5-7). Moreover, dysregulation is observed in glucocorticoid secretion under pathological conditions $(8,9)$. An example of this is in obesity, where several studies in humans report $(8,10-12)$ an increase of cortisol secretion directly from the adrenal gland, yet the circulating plasma levels are normal, potentially due to higher metabolic clearance rate.

A variety of growth factors, neuropeptides, cytokines and adipokines have been demonstrated to affect adrenal secretions. Correspondingly, adrenocortical cells express receptors for each of these factors $(13,14)$. In vitro studies found that vital glucose regulating-peptides also have the capacity 
to regulate ACTH-stimulated glucocorticoid secretion. More specifically, insulin inhibits cortisol secretion from bovine adrenocortical cells (15), while glucagon inhibits cortisol secretion from human adrenocortical cells $(16,17)$. The satiety factor leptin was found to directly regulate adrenal secretions via its receptors on adrenocortical cells $(18,19)$. Likewise, the gut-derived incretin hormone glucagon-like peptide 1 (GLP-1) was also shown to inhibit glucocorticoid release from rat adrenal cortex in response to $\mathrm{ACTH}$, by decreasing the activation of adenylate cyclase and by impairing the late steps of glucocorticoid synthesis (17). Nonetheless, intracerebroventricular, intravenous, and intraperitoneal administration of GLP-1 increased circulating levels of cortisol in rats, a change preceded by an increase in ACTH levels $(20,21)$. The mechanisms through which circulating GLP-1 activate the HPA axis remain to be elucidated, and may provide further evidence for the beneficial effect of GLP-1 receptor agonists in obesity and type 2 diabetes (T2DM) treatment.

\section{1 $\beta$-Hydroxysteroid Dehydrogenases}

Although the regulation of glucocorticoid secretion is an important means of their action, the effects of glucocorticoids on target tissues such as liver and adipose tissue are dependent on metabolism by $11 \beta$-hydroxysteroid dehydrogenases (11 $\beta$ HSDs), with the notable exception of pancreatic $\beta$-cells (22). $11 \beta$-HSD1 is present in most cells and tissues and acts predominantly as an NADPH-dependent reductase to regenerate the active glucocorticoid receptor (GR) ligand cortisol (or corticosterone, in rodents) from inactive cortisone (Figure 1) (23). Conversely, $11 \beta$-HSD2 inactivates cortisol by converting it into cortisone, thereby protecting the mineralocorticoid receptor from cortisol ligands. $11 \beta-\mathrm{HSD} 2$ is largely expressed in the kidney, placenta, and colon whereas the principle sites of $11 \beta$ HSD1 expression are liver, adipose tissue and muscle (24). The A-ring reductases, 5-reductase types 1 and 2 (5R1 and 5R2) convert cortisol and cortisone to their dihydrometabolites, and these are next converted to tetrahydrometabolites through the action of 3-hydroxysteroid dehydrogenase $(25,26)$. Total glucocorticoid production can be estimated by analyzing the sum of glucocorticoid metabolites in a $24 \mathrm{~h}$ urinary sample. The relative excretion of cortisol to cortisonemetabolites [ $5 \mathrm{a}-\mathrm{THF}+$ $\mathrm{THF}+\mathrm{a}$-cortol $) /(\mathrm{THE}+\mathrm{a}$-cortolone $)]$ reflects the global activity of $11 \beta$-HSD 1 (27).

Glucocorticoid metabolism at the tissue level is dysregulated in human obesity, with increased 5-reductase activity and decreased cortisol levels in the liver (28-30). Contrariwise, $11 \beta$-HSD1 activity is increased in adipose tissue, which increases tissue glucocorticoid levels. Mice overexpressing $11 \beta$ HSD1 in adipose tissue develop visceral obesity, insulin resistance, dyslipidaemia, and hypertension (31), while liverspecific 11 $\beta$-HSD1 overexpression results in insulin resistance and hypertension, but not obesity (32). Interestingly, 11 $\beta$-HSD1 appears to be absent from pancreatic $\alpha$ and $\beta$ - cells though present in other cell types in the mouse and human islet $(22,33)$. Selective $11 \beta$-HSD1 inhibitors have been shown to lower glucose intolerance and reduce food intake and weight gain in hyperglycaemic mouse models (34-36). 11 $\beta$-HSD1 knockout mice are resistant to hyperglycaemia when fed a high-fat diet and show reduced expression of mRNA encoding the key hepatic gluconeogenic enzyme phosphoenolpyruvate carboxykinase (PCK1) (37). Overall, these studies place $11 \beta$ HSD1 in a central position of cortisol metabolism and suggest that its inhibition may be a key target for diabetes and obesity treatments, especially as a mediator of insulin sensitivity. Nonetheless, the differential regulation of $11 \beta-H S D 1$ between organs implies a more complex pathway that may require equal attention to be paid to $11 \beta$-HSD2.

\section{Glucocorticoid Receptors (GR)}

The function of glucocorticoids, both at a physiological and pharmacological level, is mediated by the GR. The GR is a member of the nuclear receptor superfamily of liganddependent transcription factors and its gene is regulated by both developmental and tissue-specific factors (38). Activated GR controls the expression of thousands of genes, either by inducing or inhibiting their transcription through DNA binding (39-41). The GR is composed of three main domains; the N-terminal transactivation, the central DNA-binding and the C-terminal ligand binding domains, with the central domain containing two zinc fingers. In the absence of glucocorticoids, GR is located primarily in the cytoplasm inside a large multi-protein complex. Once glucocorticoids are bound, GR dissociates from the complex and exposes two nuclear localization signals. GR then rapidly translocates into the nucleus through nuclear pores and, once inside, binds directly to glucocorticoid-responsive elements (GRE) and regulates the expression of target genes (Figure 1) (42). Our understanding of the role of the GR protein has changed dramatically within the last decade, as it is now accepted that the GR gene can be spliced into a large group of receptor isoforms, each with a different expression and function that widens the glucocorticoid diversity of GR action (43). Moreover, although this review focuses on the genomic mechanism of glucocorticoid function, several studies have demonstrated a rapid, non-genomic action mechanism that does not involve gene expression alteration and may involve an, as yet uncharacterised, receptor located at the plasma membrane (44-46).

Glucocorticoids acting through the GR regulate glucose metabolism in the liver, skeletal muscle, adipose tissue, and the pancreas, by controlling the expression of key enzymes. However, in obesity, cortisol levels remain at near normal concentrations, pointing to intracellular control of GR action in these circumstances. This suggests that GR polymorphisms might be responsible for the pathophysiology and evolution of obesity and diabetes $(47,48)$. The GR levels and activity have also been linked to diabetes pathogenesis, as increased hepatic GR mRNA induces activation of phosphoenolpyruvate carboxykinase (PEPCK), which results in hyperglycaemia and insulin resistance in diabetic obese mice and obese Zucker rats $(49,50)$. This observation was also made in human skeletal muscle, as increased GR was linked to the metabolic syndrome (51). Furthermore, general and hepatic inactivation of GR, achieved through the use of antagonists, was shown to improve glucose tolerance and insulin resistance in diabetic animals (52-54). The mass emerging observations on GR 


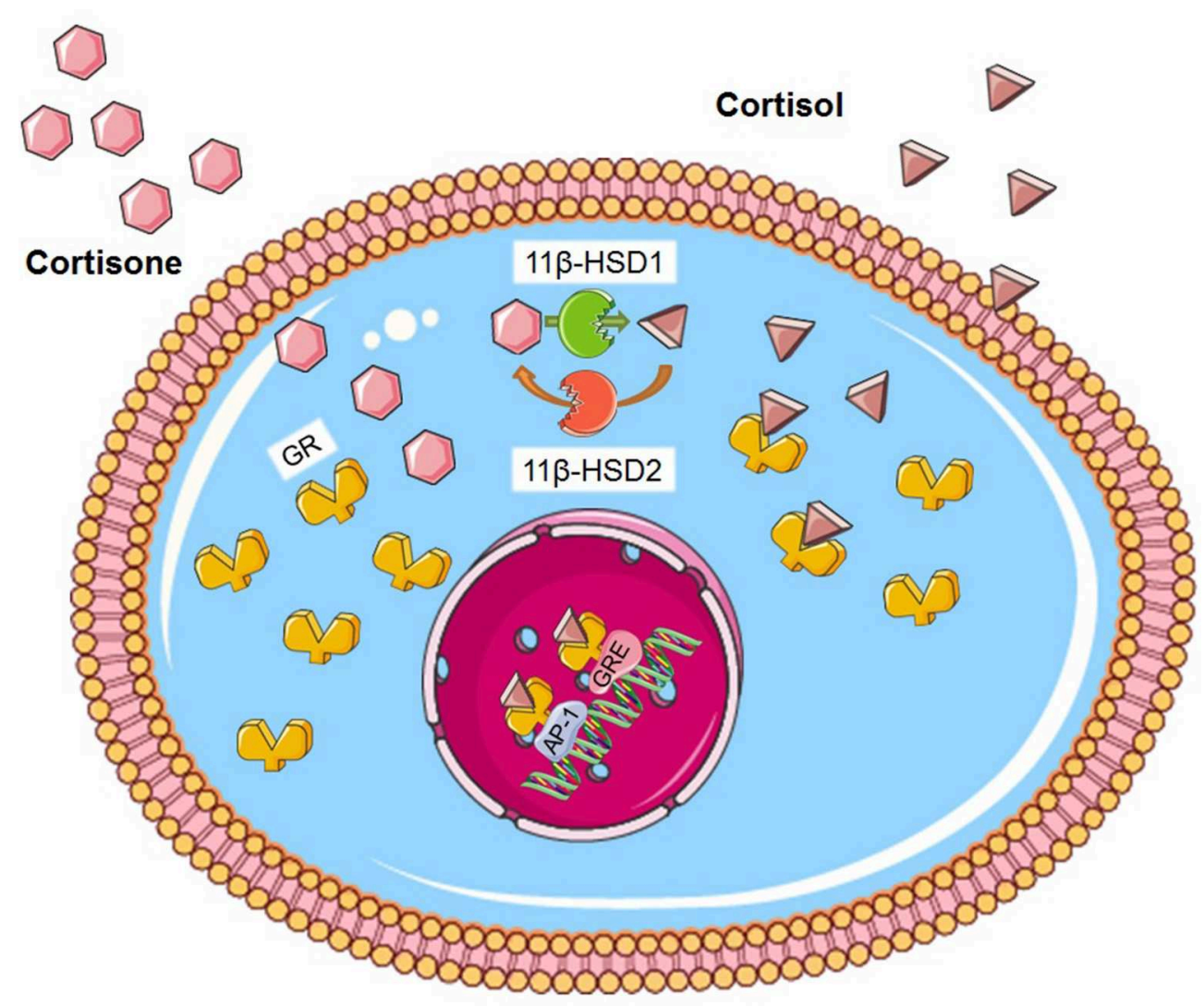

FIGURE 1 | Glucocorticoid metabolism. Cortisone is activated to cortisol by the enzyme 11 $\beta$-HSD1. Conversely, 11 $\beta$-HSD2 inactivates cortisol by converting it into cortisone. GR is found in the cytosol. Cortisol binds on the GR and the ligand-receptor complex translocates to the nucleus where in can bind on GRE or to different transcription factors such as AP-1. Figure was created using Servier Medical Art.

polymorphism could further indicate which receptor subtype can be a disease risk indicator, as well as improve specificity for GR antagonism treatment.

\section{METABOLIC FUNCTION OF GLUCOCORTICOIDS}

Glucocorticoids are involved in metabolic, inflammatory, cardiovascular, and behavioral processes. Thus, as mentioned above, they modulate the transcription of a variety of genes, including cytokines and chemokines, receptors, enzymes, adhesion molecules, and inhibitory proteins. Clinical observations linking high glucocorticoid levels to the metabolic syndrome provided evidence for their role on diabetes and obesity (55). The metabolic effects of glucocorticoids are linked to physiological mechanisms that are associated with hepatic and peripheral insulin resistance, hyperglycaemia, and dyslipidaemia. In the liver, glucocorticoids stimulate gluconeogenesis by activating PEPCK and glucose-6-phosphatase (G6Pase) (56). Moreover, in the fasting condition, glucocorticoids stimulate lipolysis in adipocytes, resulting in generation of glycerol to be utilized in gluconeogenesis and free fatty acids to be oxidized and get used as energy $(57,58)$. Although glucocorticoids are important for the maintenance of lipid homeostasis, excess glucocorticoids can result in an increase the circulating free fatty acids and induce lipid accumulation in skeletal muscle and liver, both of which are associated with insulin resistance (59-61). In rat skeletal muscle, glucocorticoid excess can also inhibit the translocation of GLUT4 glucose transporters to the plasma membrane in response to insulin, resulting in insulin resistance (Figure 2) (62). In human adipose tissue, glucocorticoids induce adipocyte differentiation leading to increased adiposity and insulin resistance (63-65).

The link between glucocorticoids and T2DM is strong, yet the effect of glucocorticoids on the endocrine pancreas remains controversial. The study of transgenic mice overexpressing the GR selectively in the $\beta$-cell indicated that glucocorticoids may directly inhibit insulin release in vivo (66). Correspondingly, several in vitro studies have demonstrated an inhibitory effect of glucocorticoids on mouse islets $(67,68)$. The function of $11 \beta$-HSD1 in mouse and human islets has been examined in vitro, and data suggest direct control over $\alpha$-cell glucagon release and a paracrine effect on insulin secretion (69). In islets obtained from diabetic obese mice, glucocorticoid administration 


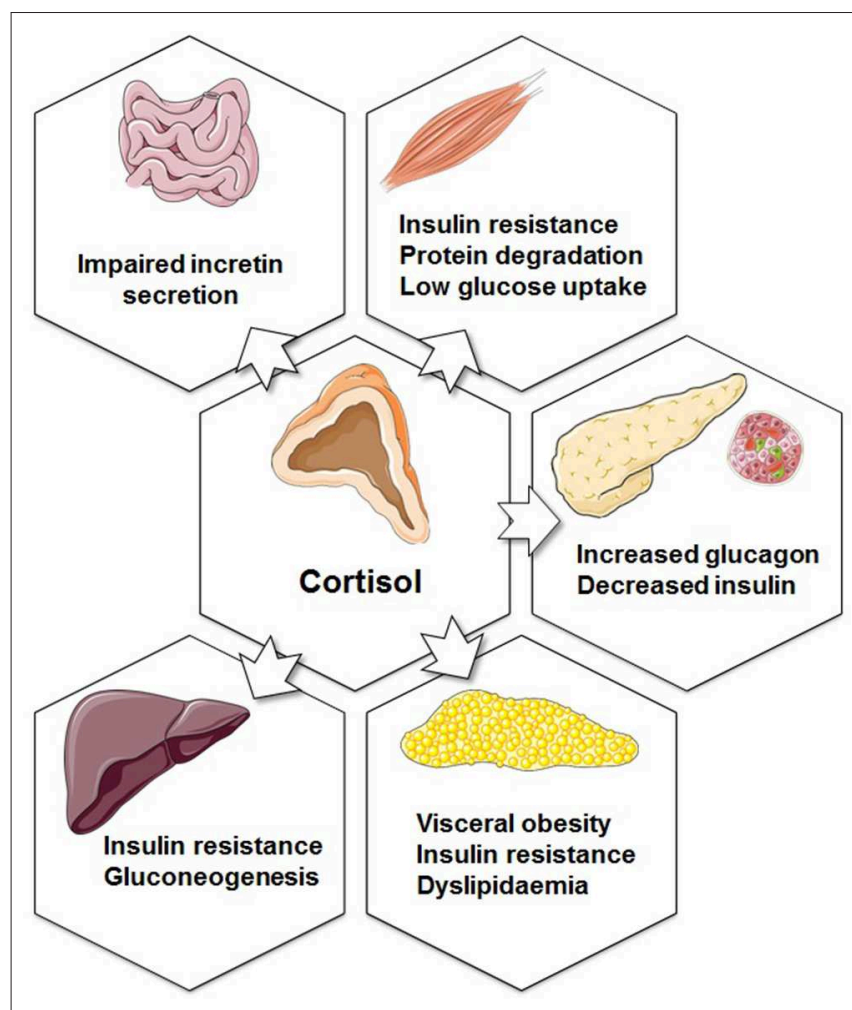

FIGURE 2 | Metabolic functions of glucocorticoids. The effects of increased cortisol secretion on the endocrine pancreas, adipose tissue, liver, muscle, and gastrointestinal system. Figure was created using Servier Medical Art.

up regulated $11 \beta$-HSD1 causing impaired insulin secretion. This effect was abolished by GR antagonist or an $11 \beta$-HSD1 inhibitor (70).

Glucocorticoids have also been associated with pancreatic development. Treatment of fetal rats with dexamethasone reduced $\beta$-cell insulin content and examination of embryonic pancreata from glucocorticoid-treated animals revealed a decrease of insulin-producing cells and an increase in exocrine cells, possibly the result of down-regulation of pancreas maturation transcription factors such as Pdx1, Pax6, and Nkx6.1 (71, 72). However, islets from Wistar rats treated with dexamethasone for 5 days showed an enhanced insulin release in response to glucose, with an increased number of insulin granules docked at the plasma membrane observed in $\beta$-cells (73). Transgenic mice overexpressing $11 \beta$-HSD1 selectively to the $\beta$-cell displayed a reversal of high fat-induced $\beta$-cell failure. This was due to the expansion of $\beta$-cell population and the function of small islets, the latter being linked to protein kinase A and p21 signaling pathways (74). Finally, corticosterone, cortisol, and cortisone suppressed voltage-dependent $\mathrm{Ca}^{2+}$ channel activity in human and rodent $\beta$-cells, while in parallel amplifying cAMP signals and increasing the number of membrane-docked insulin secretory granules. Interestingly, no changes were observed in glucose-stimulated insulin secretion nor in the maximal ATP/ADP responses to glucose (75).

\section{GLUCOCORTICOIDS AND WEIGHT LOSS}

\section{Diet and Exercise}

Although a link between glucocorticoids and obesity has been reported in many studies, it is still unclear what changes following weight loss. Tomlinson et al. (76) reported the effects of weight loss on glucocorticoids in patients with obesity on very low calorie diet. Even though circulating cortisol and cortisone concentrations did not change with weight loss, the 0900h cortisol/cortisone ratio increased, indicating a shift in set-point toward cortisol generation consistent with increased $11 \beta$-HSD1 activity. Expression of $11 \beta$-HSD1 in whole adipose tissue did not change with weight loss but did increase in isolated adipocytes. No other corticosteroid was affected. A follow-up of this study (77) showed that total glucocorticoid secretion in this scenario decreased post-diet-induced weight loss. However, urinary steroid metabolite ratios that reflect $11 \beta$ HSD1 activity did not change. Moreover, increased cortisol availability within adipose tissue interstitial fluid was shown after weight loss.

In men with weight loss following 6 months of dieting, cortisol production rate, free cortisol levels and metabolic clearance rate did not change when compared to baseline (78). Nonetheless, with greater weight loss and decreased body fat, both cortisol production and free cortisol levels increased, whilst adipose $11 \beta$-HSD-1 decreased, compared to baseline (78). One week of caloric restriction in men also failed to reveal any change in cortisol levels (79). These results were further investigated in overweight/obese post-menopausal women following dietinduced weight loss with contradictory results. In one study (80), 11 $\beta$-HSD1 expression in adipose tissue was decreased postweight loss and this reduction was correlated with a reduction in BMI between baseline and 6 months post-diet initiation. In contrast, a previous study showed that weight reduction did not impact gene expression levels of $11 \beta$-HSD1 in adipose tissue (81).

Glucocorticoids respond acutely to changes in nutritional status, with cortisol levels increasing within minutes following a meal $(82,83)$. Given the discrepancies between studies, as well as differences in human and rodent data, it became clear that the type of meal in each diet had to be specified and specific dietary macronutrients were investigated with regards to their effect on metabolism (84). A high fat-low carbohydrate diet increased whole body $11 \beta$-HSD1 activity and decreased $5 \mathrm{a}-$ and $5 b$-reductase activities in men, compared with a moderate fatmoderate carbohydrate diet, with no effect on subcutaneous adipose tissue $11 \beta$-HSD1 (84). In rodents, although there was no difference between low carbohydrate and moderate carbohydrate diets, hepatic $11 \beta$-HSD1 mRNA was reduced in both diets when compared with a high fat Western diet (85).

Apart from diet, exercise is a common treatment for weight loss. However, exercise is also a form of metabolic stress which can stimulate the HPA axis and lead to increased levels of circulating glucocorticoids $(86,87)$. The importance of this has been investigated by separating acute intense and chronic voluntary exercises in rats on treadmill running, where intense exercise studies have shown higher corticosterone levels in urine, enlargement of the adrenal glands and reduced adrenal sensitivity 
to ACTH, as indicated by low ACTH-to-glucocorticoid ratio (88, 89), whether regular and voluntary exercise increased adrenal sensitivity, demonstrating that long-term training balances glucocorticoid fluctuations $(86,90)$.

Although increased glucocorticoid concentration can indeed have a negative impact in pancreatic $\beta$-cells alone (91), regular exercise can improve insulin sensitivity and glucose tolerance and this could be attributed to tissular, rather than systemic, glucocorticoid metabolism. It has previously been shown that exercise can lead to reduced expression of the glucocorticoid receptor and $11 \beta-\mathrm{HSD} 1$ in muscle and liver, yet unchanged circulating cortisol, in hamsters (87). Importantly, previous studies in humans and rodents have demonstrated that various types of exercise are able to improve insulin sensitivity, by recovering the function of specific insulin signaling proteins such as Akt and IRS-1 and also augment GLUT-4 expression (9297). Insulin-stimulated glucose uptake in muscle, impaired by exposure to glucocorticoids, can also be enhanced by exercise. The effects of exercise appear to involve increased activation of insulin signal via Akt and IRS1 in rodents, as well as slow the glucocorticoid-induced muscle atrophy. This appears to improve through a combination of increases in $\mathrm{MTOR}$ and its downstream target $\mathrm{p} 70 \mathrm{~S} 6 \mathrm{~K}$ protein, and a small increase in MuRF-1 protein level, the latter a regulator of proteasome-dependent degradation of muscle proteins (94-96). To date, studies have been able to demonstrate that exercise is able to attenuate exogenous glucocorticoid-induced hyperglycaemia, while less is known about its effect on endogenous glucocorticoids.

Overall, reporting on the relationship between cortisol levels, obesity and weight loss has been challenging, especially if cortisol was measured in the serum, urine or saliva which would provide a snapshot in time rather than continuous reporting. This is most likely due to the fact that cortisol is secreted in a pulsatile manner, affected by the circadian rhythm, environmental circumstances and stress (98), which could even be diet-induced. In addition, gender and adiposity location also appear to have an effect on results. It is therefore important to remember that not all patients with obesity will demonstrate similar cortisol secretion and metabolism, especially at baseline level. Chronic cortisol measurement may provide a more appropriate and ubiquitous way to report changes in glucocorticoid metabolism, potentially by using hair cortisol measurements (99-102), which has been shown to be a novel and accurate way to measure average systemic cortisol levels.

\section{Bariatric Surgery}

Bariatric surgery, and particularly Roux-en-Y gastric bypass (RYGB), causes sustained weight loss in individuals with morbid obesity, as well as dramatic and rapid improvement of T2DM, dyslipidaemia, hypertension and a significant reduction of cardiovascular disease and death (103). Although the effects of RYGB on diabetes were initially attributed to the substantial weight loss subsequent to post-operative restriction of nutrient intake and/or absorption, the same effect was demonstrated in rodents that did not experience weight loss, suggesting a mechanism of action that is weight independent. Moreover, the improvements are observed within hours and days, long before substantial weight loss occurred.

In an effort to understand the underlying mechanisms of diabetes remission, this observation has since led to numerous investigations on the glucoregulatory role of the gastrointestinal tract, including the role of an increase in observed post-operative GLP-1 concentration. This includes the "hindgut hypothesis" which holds that euglycaemic effects are derived from the expedited delivery of nutrients to the distal intestine, where GLP-1 is primarily secreted, and therefore enhances the insulin signal that improves glucose metabolism (104). Few data are available regarding the specific modifications in glucocorticoid metabolism after bariatric surgery in human obesity. Given the numerous endocrine changes following surgery, one might expect to have a conclusive picture of glucocorticoid metabolism post-operatively. The fact that this is the case due to different surgical procedures, as well as alterations of the same procedures, which can cause perioperative stress and different levels of caloric restriction and weight loss.

Several observations have linked bariatric surgery to glucocorticoid metabolism, notably in the context of postoperative adipose tissue reduction. Woods et al. investigated the activity and expression of $11 \beta$-HSD1 in hepatic and adipose tissue before and $\sim 14$ months after RYGB, revealing a postoperative increase in hepatic $11 \beta$-HSD1 activity, as inferred from a by raised serum cortisol/costisone ratio (F/E) (105). However, subcutaneous adipose tissue $11 \beta$-HSD1 activity was decreased, as showed by the tissue's F/E. Moreover, total urinary cortisol metabolites were reduced, suggesting a reduction in HPA axis activity (105). The decrease of subcutaneous adipose tissue $11 \beta$-HSD1 activity at 1 and 2 years after gastric bypass surgery in humans has also been reported through both mRNA expression and urine and adipose tissue $\mathrm{F} / \mathrm{E}$, along with positive changes in insulin sensitivity, circulating leptin, and adiponectin, and peripheral glucocorticoid metabolism (106108). Additionally, intra-adipose levels of cortisone, rather than cortisol, demonstrated the most obvious changes, suggesting that the altered glucocorticoid metabolism after weight loss may be an adaptive response to insufficient levels of adipose cortisol. Of note, supplementary data in Methlie et al. (108), show that obese patients at 1 year post-RYGB demonstrated a significant reduction of adipose tissue $\mathrm{F} / \mathrm{E}$, when compared to non-obese controls. This observation points to an effect potentially caused by more than surgery-induced weight loss and may include the gastrointestinal tract manipulation itself. One potential mechanism could be the effect of post-operatively increased GLP-1 on glucocorticoid regulation, as discussed before. Taken together, the reduction in glucocorticoid exposure in subjects with obesity may represent an additional possible contribution to the health benefits of bariatric surgery.

\section{DISCUSSION}

Glucocorticoids are steroid hormones that are crucial for the preservation of homeostasis. Their physiological and therapeutic effects have made them key targets for drug development, 
primarily as anti-inflammatory agents. Nonetheless, their side effects can be severe, especially in terms of metabolism. In this review, we provide an overview of the physiology glucocorticoid regulation, metabolism, and signaling pathways, as well as their effects on obesity and diabetes. We also discussed the ability of weight loss to reverse some of these effects.

Overall, high glucocorticoid levels are associated with hyperglycaemia and insulin resistance and affect key metabolic organs such as the pancreas, liver, muscle and adipose tissue $(28,30,107,109)$. Of note, the exact mechanism of glucocorticoid action remains controversial in pancreatic islets, especially in insulin secretion during glucocorticoid treatment (66-68). Glucocorticoid metabolism is largely controlled by $11 \beta$-HSD1 and GR and has been shown to be strongly linked to Body Mass Index, as intra-adipose cortisol levels are increased relative to inactive cortisone in the obese state, even if circulating cortisol levels remain stable. Weight loss through diet, exercise, and bariatric surgery is linked to reduced glucocorticoid secretion and function, possibly through the recovery of insulin sensitivity and function of insulin sensitivity proteins. In all three weight loss interventions, the expression levels of $11 \beta$-HSD1 in adipose tissue and liver remains a matter of debate, as studies report both increasing and decreasing levels (78-80, 107, 108). Moreover, acute cortisol measurements are presented, through serum and plasma samples. It is therefore vital to measure chronic cortisol levels to get a longer-term picture of cortisol alterations, and investigate the role of $11 \beta$-HSD1 and GR following rapid weight loss in patients, especially following bariatric surgery which is

\section{REFERENCES}

1. Smith SM, Vale WW. The role of the hypothalamic-pituitary-adrenal axis in neuroendocrine responses to stress. Dialogues Clin Neurosci. (2006) 8:383-95.

2. Adriana Del Rey GC, Besedovsky H. The Hypothalamus-Pituitary-Adrenal Axis. The Hypothalamus-Pituitary-Adrenal Axis. 7.1 Edn. Amsterdam: Elsevier Science (2008).

3. Bornstein SR, Engeland WC, Ehrhart-Bornstein M, Herman JP. Dissociation of ACTH and glucocorticoids. Trends Endocrinol Metab. (2008) 19:175-80. doi: 10.1016/j.tem.2008.01.009

4. Engeland WC, Shinsako J, Winget CM, Vernikos-Danellis J, Dallman MF. Circadian patterns of stress-induced ACTH secretion are modified by corticosterone responses. Endocrinology. (1977) 100:138-47. doi: 10.1210/endo-100-1-138

5. Vazquez DM, Morano MI, Taylor L, Akil H. Kinetics of radiolabeled adrenocorticotropin hormone in infant and weanling rats. $J$ Neuroendocrinol. (1997) 9:529-36. doi: 10.1046/j.1365-2826.1997.00608.x

6. Dhillo WS, Kong WM, Le Roux CW, Alaghband-Zadeh J, Jones J, Carter G, et al. Cortisol-binding globulin is important in the interpretation of dynamic tests of the hypothalamic-pituitary-adrenal axis. Eur J Endocrinol. (2002) 146:231-5. doi: 10.1530/eje.0.1460231

7. Gardner DS, Fletcher AJ, Fowden AL, Giussani DA. Plasma adrenocorticotropin and cortisol concentrations during acute hypoxemia after a reversible period of adverse intrauterine conditions in the ovine fetus during late gestation. Endocrinology. (2001) 142:589-98. doi: 10.1210/endo.142.2.7980

8. Vierhapper H, Nowotny P, Waldhausl W. Production rates of cortisol in obesity. Obes Res. (2004) 12:1421-5. doi: 10.1038/oby.2004.178

9. Stewart PM, Boulton A, Kumar S, Clark PM, Shackleton CH. Cortisol metabolism in human obesity: impaired cortisone->cortisol conversion in currently the least published field. This will help us determine if the positive observations on glucocorticoid metabolism are due to weight loss or if direct or indirect gastrointestinal manipulation can also have an effect.

\section{AUTHOR CONTRIBUTIONS}

EA prepared the first draft and revised the manuscript. LG and GR revised the manuscript.

\section{FUNDING}

EA was supported by a grant from the Rosetrees Trust (M825) and from the British Society for Neuroendocrinology. GR was supported by a Wellcome Trust Investigator (212625/Z/18/Z) Award, MRC Programme grants (MR/R022259/1, MR/J0003042/1, MR/L020149/1), and Experimental Challenge Grant (DIVA, MR/L02036X/1), MRC (MR/N00275X/1), and Diabetes UK (BDA/11/0004210, BDA/15/0005275, BDA 16/0005485) grants. This project has received funding from the European Union's Horizon 2020 research and innovation programme via the Innovative Medicines Initiative 2 Joint Undertaking under grant agreement No. 115881 (RHAPSODY) to GR. LG was supported by the Institute of Cardiometabolism and Nutrition, Société Française de Chirurgie Digestive, Fondation Obélisque, APPERT Institute, and Société Française et Francophone de l'obésité et des maladies métaboliques. subjects with central adiposity. J Clin Endocrinol Metab. (1999) 84:1022-7. doi: $10.1210 /$ jc. 84.3 .1022

10. Andrew R, Phillips DI, Walker BR. Obesity and gender influence cortisol secretion and metabolism in man. J Clin Endocrinol Metab. (1998) 83:18069. doi: $10.1210 /$ jcem.83.5.4951

11. Phillips DIW, Barker DJP, Fall CHD, Seckl JR, Whorwood CB, Wood PJ, et al. Elevated plasma cortisol concentrations: a link between low birth weight and the insulin resistance syndrome? J Clin Endocr Metab. (1998) 83:757-60. doi: 10.1210/jcem.83.3.4634

12. Strain GW, Zumoff B, Kream J, Strain JJ, Levin J, Fukushima D. Sex Difference in the influence of obesity on the 24-hr mean plasma-concentration of cortisol. Metabolism. (1982) 31:209-12. doi: 10.1016/0026-0495(82)90054-3

13. Bornstein SR, Chrousos GP. Clinical review 104: Adrenocorticotropin (ACTH) - and non-ACTH-mediated regulation of the adrenal cortex: neural and immune inputs. J Clin Endocrinol Metab. (1999) 84:1729-36. doi: 10.1210/jcem.84.5.5631

14. Lamounier-Zepter V, Ehrhart-Bornstein M, Bornstein SR. Metabolic syndrome and the endocrine stress system. Horm Metab Res. (2006) 38:437-41. doi: 10.1055/s-2006-947837

15. Klein NA, Andersen RN, Casson PR, Buster JE, Kramer RE. Mechanisms of insulin-inhibition of acth-stimulated steroid-secretion by cultured bovine adrenocortical-cells. J Steroid Biochem. (1992) 41:11-20. doi: 10.1016/0960-0760(92)90219-9

16. Andreis PG, Malendowicz LK, Neri G, Tortorella C, Nussdorfer GG. Effects of glucagon and glucagon-like peptide-1 on glucocorticoid secretion of dispersed rat adrenocortical cells. Life Sci. (1999) 64:2187-97. doi: 10.1016/S0024-3205(99)00170-8

17. Mazzocchi G, Gottardo L, Aragona F, Albertin G, Nussdorfer GG. Glucagon inhibits ACTH-stimulated cortisol secretion from dispersed human adrenocortical cells by activating unidentified receptors negatively 
coupled with the adenylate cyclase cascade. Horm Metab Res. (2000) 32:2658. doi: 10.1055/s-2007-978633

18. Bornstein SR, Uhlmann K, Haidan A, EhrhartBornstein M, Scherbaum WA. Evidence for a novel peripheral action of leptin as a metabolic signal to the adrenal gland - Leptin inhibits cortisol release directly. Diabetes. (1997) 46:1235-8. doi: 10.2337/diab.46.7.1235

19. Glasow A, Bornstein SR. Leptin and the adrenal gland. Eur J Clin Invest. (2000) 30:39-45. doi: 10.1046/j.1365-2362.2000.0300s3039.x

20. Kinzig KP, D’Alessio DA, Herman JP, Sakai RR, Vahl TP, Figueredo HF, et al. CNS glucagon-like peptide-1 receptors mediate endocrine and anxiety responses to interoceptive and psychogenic stressors. J Neurosci. (2003) 23:6163-70. doi: 10.1523/JNEUROSCI.23-15-06163.2003

21. Gil-Lozano M, Perez-Tilve D, Alvarez-Crespo M, Martis A, Fernandez AM, Catalina PAF, et al. GLP-1(7-36)-amide and exendin-4 stimulate the HPA axis in rodents and humans. Endocrinology. (2010) 151:2629-40. doi: 10.1210/en.2009-0915

22. Pullen TJ, Huising MO, Rutter GA. Analysis of purified pancreatic islet beta and alpha cell transcriptomes reveals 11beta-hydroxysteroid dehydrogenase (Hsd11b1) as a novel disallowed gene. Front Genet. (2017) 8:41. doi: 10.3389/fgene.2017.00041

23. Rebuffescrive M, Bronnegard M, Nilsson A, Eldh J, Gustafsson JA, Bjorntorp P. Steroid-hormone receptors in human adipose tissues. J Clin Endocr Metab. (1990) 71:1215-9. doi: 10.1210/jcem-71-5-1215

24. Liu YJ, Nakagawa Y, Ohzeki T. Gene expression of 11 beta-hydroxysteroid dehydrogenase type 1 and type 2 in the kidneys of insulin-dependent diabetic rats. Hypertension. (1998) 31:885-9. doi: 10.1161/01.HYP.31.3.885

25. Palermo M, Shackleton CHL, Mantero F, Stewart PM. Urinary free cortisone and the assessment of 11 beta-hydroxysteroid dehydrogenase activity in man. Clin Endocrinol. (1996) 45:605-11. doi: 10.1046/j.1365-2265.1996.00853.x

26. Rogers SL, Hughes BA, Jones CA, Freedman L, Smart K, Taylor N, et al. Diminished 11 beta-hydroxysteroid dehydrogenase type 2 activity is associated with decreased weight and weight gain across the first year of life. J Clin Endocr Metab. (2014) 99:E821-E31. doi: 10.1210/jc.2013-3254

27. Andrew R, Smith K, Jones GC, Walker BR. Distinguishing the activities of 11 beta-hydroxysteroid dehydrogenases in vivo using isotopically labeled cortisol. J Clin Endocr Metab. (2002) 87:277-85. doi: 10.1210/jc.87.1.277

28. Livingstone DE, Jones GC, Smith K, Jamieson PM, Andrew R, Kenyon CJ, et al. Understanding the role of glucocorticoids in obesity: tissue-specific alterations of corticosterone metabolism in obese Zucker rats. Endocrinology. (2000) 141:560-3. doi: 10.1210/endo.141.2.7297

29. Rask E, Olsson T, Soderberg S, Andrew R, Livingstone DE, Johnson O, et al. Tissue-specific dysregulation of cortisol metabolism in human obesity. J Clin Endocrinol Metab. (2001) 86:1418-21. doi: 10.1210/jcem.86.3.7453

30. Stomby A, Andrew R, Walker BR, Olsson T. Tissue-specific dysregulation of cortisol regeneration by 11betaHSD1 in obesity: has it promised too much? Diabetologia. (2014) 57:1100-10. doi: 10.1007/s00125-014-3228-6

31. Masuzaki H, Paterson J, Shinyama H, Morton NM, Mullins JJ, Seckl JR, et al. A transgenic model of visceral obesity and the metabolic syndrome. Science. (2001) 294:2166-70. doi: 10.1126/science.1066285

32. Paterson JM, Morton NM, Fievet C, Kenyon CJ, Holmes MC, Staels B, et al. Metabolic syndrome without obesity: hepatic overexpression of 11 betahydroxysteroid dehydrogenase type 1 in transgenic mice. Proc Natl Acad Sci USA. (2004) 101:7088-93. doi: 10.1073/pnas.0305524101

33. Fine NHF, Doig CL, Elhassan YS, Vierra NC, Marchetti P, Bugliani M, et al. Glucocorticoids reprogram beta-cell signaling to preserve insulin secretion. Diabetes. (2018) 67:278-90. doi: 10.2337/db16-1356

34. Alberts P, Nilsson C, Selen G, Engblom LOM, Edling NHM, Norling $\mathrm{S}$, et al. Selective inhibition of 11 beta-hydroxysteroid dehydrogenase type 1 improves hepatic insulin sensitivity in hyperglycemic mice strains. Endocrinology. (2003) 144:4755-62. doi: 10.1210/en.2003-0344

35. Wang SJY, Birtles S, de Schoolmeester J, Swales J, Moody G, Hislop D, et al. Inhibition of 11 beta-hydroxysteroid dehydrogenase type 1 reduces food intake and weight gain but maintains energy expenditure in diet-induced obese mice. Diabetologia. (2006) 49:1333-7. doi: 10.1007/s00125-006-0239-y

36. Liu YJ, Nakagawa Y, Wang Y, Liu LM, Du HW, Wang W, et al. Reduction of hepatic glucocorticoid receptor and hexose-6-phosphate dehydrogenase expression ameliorates diet-induced obesity and insulin resistance in mice. $J$ Mol Endocrinol. (2008) 41:53-64. doi: 10.1677/JME-08-0004
37. Kotelevtsev Y, Holmes MC, Burchell A, Houston PM, Schmoll D, Jamieson $\mathrm{P}$, et al. 11 beta-hydroxysteroid dehydrogenase type 1 knockout mice show attenuated glucocorticoid-inducible responses and resist hyperglycemia on obesity or stress. Proc Natl Acad Sci USA. (1997) 94:14924-9. doi: 10.1073/pnas.94.26.14924

38. Kalinyak JE, Griffin CA, Hamilton RW, Bradshaw JG, Perlman AJ, Hoffman AR. Developmental and hormonal-regulation of glucocorticoid receptor messenger-RNA in the rat. J Clin Invest. (1989) 84:1843-8. doi: $10.1172 / J C I 114370$

39. Evans RM. The steroid and thyroid-hormone receptor superfamily. Science. (1988) 240:889-95. doi: 10.1126/science.3283939

40. Oakley RH, Cidlowski JA. The biology of the glucocorticoid receptor: new signaling mechanisms in health and disease. J Allergy Clin Immunol. (2013) 132:1033-44. doi: 10.1016/j.jaci.2013.09.007

41. Scheschowitsch K, Leite JA, Assreuy J. New insights in glucocorticoid receptor signaling-more than just a ligand-binding receptor. Front Endocrinol. (2017) 8:16. doi: 10.3389/fendo.2017.00016

42. Beato M. Gene-Regulation by Steroid-Hormones. Cell. (1989) 56:335-44. doi: 10.1016/0092-8674(89)90237-7

43. van Rossum EFC, Lamberts SWJ. Polymorphisms in the glucocorticoid receptor gene and their associations with metabolic parameters and body composition. Recent Prog Horm Res. (2004) 59:333-57. doi: 10.1210/rp.59.1.333

44. Johnstone WM 3rd, Honeycutt JL, Deck CA, Borski RJ. Nongenomic glucocorticoid effects and their mechanisms of action in vertebrates. Int Rev Cell Mol Biol. (2019) 346:51-96. doi: 10.1016/bs.ircmb.2019.03.004

45. Borski RJ. Nongenomic membrane actions of glucocorticoids in vertebrates. Trends Endocrinol Metab. (2000) 11:427-36. doi: $10.1016 / \$ 1043-2760(00) 00325-8$

46. Song IH, Buttgereit F. Non-genomic glucocorticoid effects to provide the basis for new drug developments. Mol Cell Endocrinol. (2006) 246:142-6. doi: 10.1016/j.mce.2005.11.012

47. Moraitis AG, Block T, Nguyen D, Belanoff JK. The role of glucocorticoid receptors in metabolic syndrome and psychiatric illness. J Steroid Biochem. (2017) 165:114-20. doi: 10.1016/j.jsbmb.2016.03.023

48. Majer-Lobodzinska A, Adamiec-Mroczek J. Glucocorticoid receptor polymorphism in obesity and glucose homeostasis. Adv Clin Exp Med. (2017) 26:143-8. doi: 10.17219/acem/41231

49. Liu YJ, Nakagawa Y, Wang Y, Sakurai R, Tripathi PV, Lutfy K, et al. Increased glucocorticoid receptor and 11 beta-hydroxysteroid dehydrogenase type 1 expression in hepatocytes may contribute to the phenotype of type 2 diabetes in db/db mice. Diabetes. (2005) 54:32-40. doi: 10.2337/diabetes.54.1.32

50. Jenson M, Kilroy G, York DA, Braymer D. Abnormal regulation of hepatic glucocorticoid receptor mRNA and receptor protein distribution in the obese Zucker rat. Obes Res. (1996) 4:133-43. doi: 10.1002/j.1550-8528.1996.tb00525.x

51. Whorwood CB, Donovan SJ, Flanagan D, Phillips DIW, Byrne CD. Increased glucocorticoid receptor expression in human skeletal muscle cells may contribute to the pathogenesis of the metabolic syndrome. Diabetes. (2002) 51:1066-75. doi: 10.2337/diabetes.51.4.1066

52. Watts LM, Manchem VP, Leedom TA, Rivard AL, McKay RA, Bao DJ, et al. Reduction of hepatic and adipose tissue glucocorticoid receptor expression with antisense oligonucleotides improves hyperglycemia and hyperlipidemia in diabetic rodents without causing systemic glucocorticoid antagonism. Diabetes. (2005) 54:1846-53. doi: 10.2337/diabetes.54.6.1846

53. Opherk C, Tronche F, Kellendonk C, Kohlmuller D, Schulze A, Schmid $\mathrm{W}$, et al. Inactivation of the glucocorticoid receptor in hepatocytes leads to fasting hypoglycemia and ameliorates hyperglycemia in streptozotocin-induced diabetes mellitus. Mol Endocrinol. (2004) 18:1346-53. doi: 10.1210/me.2003-0283

54. John K, Marino JS, Sanchez ER, Hinds TD, Jr. The glucocorticoid receptor: cause of or cure for obesity? Am J Physiol Endocrinol Metab. (2016) 310:E249-57. doi: 10.1152/ajpendo.00478.2015

55. Andrew R, Gale CR, Walker BR, Seckl JR, Martyn CN. Glucocorticoid metabolism and the metabolic syndrome: associations in an elderly cohort. Exp Clin Endocr Diab. (2002) 110:284-90. doi: 10.1055/s-2002-34591

56. Argaud D, Zhang Q, Pan WS, Maitra S, Pilkis SJ, Lange AJ. Regulation of rat liver glucose-6-phosphatase gene expression in different nutritional and 
hormonal states-Gene structure and 5'-flanking sequence. Diabetes. (1996) 45:1563-71. doi: 10.2337/diab.45.11.1563

57. Berdanier $\mathrm{CD}$. Role of glucocorticoids in the regulation of lipogenesis. FASEB J. (1989) 3:2179-83. doi: 10.1096/fasebj.3.10.2666232

58. Xu C, He J, Jiang $\mathrm{H}, \mathrm{Zu} \mathrm{L}$, Zhai $\mathrm{W}, \mathrm{Pu} \mathrm{S}$, et al. Direct effect of glucocorticoids on lipolysis in adipocytes. Mol Endocrinol. (2009) 23:116170. doi: 10.1210/me.2008-0464

59. Samuel VT, Petersen KF, Shulman GI. Lipid-induced insulin resistance: unravelling the mechanism. Lancet. (2010) 375:2267-77. doi: 10.1016/S0140-6736(10)60408-4

60. Petersen KF, Shulman GI. Etiology of insulin resistance. Am J Med. (2006) 119(5 Suppl 1):S10-6. doi: 10.1016/j.amjmed.2006.01.009

61. Dourakis SP, Sevastianos VA, Kaliopi P. Acute severe steatohepatitis related to prednisolone therapy. Am J Gastroenterol. (2002) 97:1074-5. doi: $10.1111 / j .1572-0241.2002 .05644 . x$

62. Dimitriadis G, Leighton B, ParryBillings M, Sasson S, Young M, Krause U, et al. Effects of glucocorticoid excess on the sensitivity of glucose transport and metabolism to insulin in rat skeletal muscle. Biochem J. (1997) 321:70712. doi: 10.1042/bj3210707

63. Hauner H, Entenmann G, Wabitsch M, Gaillard D, Ailhaud G, Negrel R, et al. Promoting effect of glucocorticoids on the differentiation of human adipocyte precursor cells cultured in a chemically defined medium. J Clin Invest. (1989) 84:1663-70. doi: 10.1172/JCI114345

64. Hauner H, Schmid P, Pfeiffer EF. Glucocorticoids and insulin promote the differentiation of human adipocyte precursor cells into fat-cells. J Clin Endocr Metab. (1987) 64:832-5. doi: 10.1210/jcem-64-4-832

65. Gathercole LL, Morgan SA, Bujalska IJ, Hauton D, Stewart PM, Tomlinson JW. Regulation of lipogenesis by glucocorticoids and insulin in human adipose tissue. PLoS ONE. (2011) 6:e26223. doi: 10.1371/journal.pone.0026223

66. Delaunay F, Khan A, Cintra A, Davani B, Ling ZC, Andersson A, et al. Pancreatic beta cells are important targets for the diabetogenic effects of glucocorticoids. J Clin Invest. (1997) 100:2094-8. doi: 10.1172/JCI119743

67. Gremlich S, Roduit R, Thorens B. Dexamethasone induces posttranslational degradation of GLUT2 and inhibition of insulin secretion in isolated pancreatic beta cells - Comparison with the effects of fatty acids. J Biol Chem. (1997) 272:3216-22. doi: 10.1074/jbc.272.6.3216

68. Lambillotte C, Gilon P, Henquin JC. Direct glucocorticoid inhibition of insulin secretion - An in vitro study of dexamethasone effects in mouse islets. J Clin Invest. (1997) 99:414-23. doi: 10.1172/JCI119175

69. Swali A, Walker EA, Lavery GG, Tomlinson JW, Stewart PM. 11 beta-hydroxysteroid dehydrogenase type 1 regulates insulin and glucagon secretion in pancreatic islets. Diabetologia. (2008) 51:2003-11. doi: $10.1007 / \mathrm{s} 00125-008-1137-2$

70. Ortsater H, Alberts P, Warpman U, Engblom LOM, Abrahmsen L, Bergsten P. Regulation of 11 beta-hydroxysteroid dehydrogenase type 1 and glucosestimulated insulin secretion in pancreatic islets of Langerhans. DiabetesMetab Res. (2005) 21:359-66. doi: 10.1002/dmrr.525

71. Gesina E, Tronche F, Herrera P, Duchene B, Tales W, Czernichow P, et al. Dissecting the role of glucocorticoids on pancreas development. Diabetes. (2004) 53:2322-9. doi: 10.2337/diabetes.53.9.2322

72. Shen CN, Seckl JR, Slack JMW, Tosh D. Glucocorticoids suppress beta-cell development and induce hepatic metaplasia in embryonic pancreas. Biochem J. (2003) 375:41-50. doi: 10.1042/bj20030140

73. Rafacho A, Marroqui L, Taboga SR, Abrantes JLF, Silveira LR, Boschero AC, et al. Glucocorticoids in vivo induce both insulin hypersecretion and enhanced glucose sensitivity of stimulus-secretion coupling in isolated rat islets. Endocrinology. (2010) 151:85-95. doi: 10.1210/en.2009-0704

74. Turban S, Liu XX, Ramage L, Webster SP, Walker BR, Dunbar DR, et al. Optimal elevation of beta-cell 11 beta-hydroxysteroid dehydrogenase type 1 is a compensatory mechanism that prevents high-fat diet induced beta-cell failure. Diabetes. (2012) 61:642-52. doi: 10.2337/db11-1054

75. Fine NHF, Doig CL, Elhassan Y, Marchetti P, Bugliani M, Piemonti L, et al. Glucocorticoids re-programme the beta cell signalling cassette to preserve functional identity and insulin secretion. Diabetologia. (2017) 60:S83.

76. Tomlinson JW, Moore JS, Clark PM, Holder G, Shakespeare L, Stewart PM. Weight loss increases 11beta-hydroxysteroid dehydrogenase type 1 expression in human adipose tissue. J Clin Endocrinol Metab. (2004) 89:2711-6. doi: 10.1210/jc.2003-031376

77. Tomlinson JW, Finney J, Hughes BA, Hughes SV, Stewart PM. Reduced glucocorticoid production rate, decreased 5 alpha-reductase activity, and adipose tissue insulin sensitization after weight loss. Diabetes. (2008) 57:1536-43. doi: 10.2337/db08-0094

78. Purnell JQ, Kahn SE, Samuels MH, Brandon D, Loriaux DL, Brunzell JD. Enhanced cortisol production rates, free cortisol, and 11beta-HSD1 expression correlate with visceral fat and insulin resistance in men: effect of weight loss. Am J Physiol Endocrinol Metab. (2009) 296:E351-7. doi: 10.1152/ajpendo.90769.2008

79. Johnstone AM, Faber P, Andrew R, Gibney ER, Elia M, Lobley G, et al. Influence of short-term dietary weight loss on cortisol secretion and metabolism in obese men. Eur J Endocrinol. (2004) 150:185-94. doi: 10.1530/eje.0.1500185

80. Stomby A, Simonyte K, Mellberg C, Ryberg M, Stimson RH, Larsson C, et al. Diet-induced weight loss has chronic tissue-specific effects on glucocorticoid metabolism in overweight postmenopausal women. Int J Obes. (2015) 39:814-9. doi: 10.1038/ijo.2014.188

81. Engeli S, Bohnke J, Feldpausch M, Gorzelniak K, Heintze U, Janke J, et al. Regulation of 11beta-HSD genes in human adipose tissue: influence of central obesity and weight loss. Obes Res. (2004) 12:9-17. doi: $10.1038 /$ oby. 2004.3

82. Basu R, Singh R, Basu A, Johnson CM, Rizza RA. Effect of nutrient ingestion on total-body and splanchnic cortisol production in humans. Diabetes. (2006) 55:667-74. doi: 10.2337/diabetes.55.03.06.db05-1335

83. Wake DJ, Homer NZ, Andrew R, Walker BR. Acute in vivo regulation of 11beta-hydroxysteroid dehydrogenase type 1 activity by insulin and intralipid infusions in humans. J Clin Endocrinol Metab. (2006) 91:4682-8. doi: 10.1210/jc.2006-0819

84. Stimson RH, Johnstone AM, Homer NZ, Wake DJ, Morton NM, Andrew R, et al. Dietary macronutrient content alters cortisol metabolism independently of body weight changes in obese men. J Clin Endocrinol Metab. (2007) 92:4480-4. doi: 10.1210/jc.2007-0692

85. Stimson RH, Lobley GE, Maraki I, Morton NM, Andrew R, Walker BR. Effects of proportions of dietary macronutrients on glucocorticoid metabolism in diet-induced obesity in rats. PLoS ONE. (2010) 5:e8779. doi: 10.1371/journal.pone.0008779

86. Campbell JE, Rakhshani N, Fediuc S, Bruni S, Riddell MC. Voluntary wheel running initially increases adrenal sensitivity to adrenocorticotrophic hormone, which is attenuated with long-term training. J Appl Physiol. (1985). (2009) 106:66-72. doi: 10.1152/japplphysiol.91128.2008

87. Coutinho AE, Campbell JE, Fediuc S, Riddell MC. Effect of voluntary exercise on peripheral tissue glucocorticoid receptor content and the expression and activity of 11 beta-HSD1 in the Syrian hamster. J Appl Physiol. (2006) 100:1483-8. doi: 10.1152/japplphysiol.01236.2005

88. Chennaoui M, Gomez Merino D, Lesage J, Drogou C, Guezennec $\mathrm{CY}$. Effects of moderate and intensive training on the hypothalamopituitary-adrenal axis in rats. Acta Physiol Scand. (2002) 175:113-21. doi: 10.1046/j.1365-201X.2002.00971.x

89. Moraska A, Deak T, Spencer RL, Roth D, Fleshner M. Treadmill running produces both positive and negative physiological adaptations in Sprague-Dawley rats. Am J Physiol-Reg I. (2000) 279:R1321-R9. doi: 10.1152/ajpregu.2000.279.4.R1321

90. Dishman RK, Bunnell BN, Youngstedt SD, Yoo HS, Mougey EH, Meyerhoff JL. Activity wheel running blunts increased plasma adrenocorticotrophin (ACTH) after footshock and cage-switch stress. Physiol Behav. (1998) 63:911-7. doi: 10.1016/S0031-9384(98)00017-1

91. Fichna M, Fichna P. Glucocorticoids and beta-cell function. Endokrynol Pol. (2017) 68:568-73. doi: 10.5603/EP.2017.0060

92. Tanner CJ, Koves TR, Cortright RL, Pories WJ, Kim YB, Kahn BB, et al. Effect of short-term exercise training on insulin-stimulated PI 3-kinase activity in middle-aged men. Am J Physiol Endocrinol Metab. (2002) 282:E147-53. doi: 10.1152/ajpendo.2002.282.1.E147

93. Luciano E, Carneiro EM, Carvalho CRO, Carvalheira JBC, Peres $\mathrm{SB}$, Reis $\mathrm{MAB}$, et al. Endurance training improves responsiveness to insulin and modulates insulin signal transduction through the 
phosphatidylinositol 3-kinase/Akt-1 pathway. Eur J Endocrinol. (2002) 147:149-57. doi: 10.1530/eje.0.1470149

94. Krug ALO, Macedo AG, Zago AS, Rush JWE, Santos CF, Amaral SL. Highintensity resistance training attenuates dexamethasone-induced muscle atrophy. Muscle Nerve. (2016) 53:779-88. doi: 10.1002/mus.24906

95. Barel M, Perez OAB, Giozzet VA, Rafacho A, Bosqueiro JR, do Amaral SL. Exercise training prevents hyperinsulinemia, muscular glycogen loss and muscle atrophy induced by dexamethasone treatment. Eur J Appl Physiol. (2010) 108:999-1007. doi: 10.1007/s00421-009-1272-6

96. Hickson RC, Davis JR. Partial Prevention of Glucocorticoid-Induced Muscle Atrophy by Endurance Training. Am J Physiol. (1981) 241:E226-E32. doi: 10.1152/ajpendo.1981.241.3.E226

97. Holten MK, Zacho M, Gaster M, Juel C, Wojtaszewski JFP, Dela F. Strength training increases insulin-mediated glucose uptake, GLUT4 content, and insulin signaling in skeletal muscle in patients with type 2 diabetes. Diabetes. (2004) 53:294-305. doi: 10.2337/diabetes.53.2.294

98. Wester VL, Lamberts SW, van Rossum EF. Advances in the assessment of cortisol exposure and sensitivity. Curr Opin Endocrinol Diabetes Obes. (2014) 21:306-11. doi: 10.1097/MED.0000000000000077

99. Russell E, Kirschbaum C, Laudenslager ML, Stalder T, de Rijke Y, van Rossum EFC, et al. Toward standardization of hair cortisol measurement: results of the first international interlaboratory round robin. Ther Drug Monit. (2015) 37:71-5. doi: 10.1097/FTD.00000000000 00148

100. Wester VL, Staufenbiel SM, Veldhorst MAB, Visser JA, Manenschijn L, Koper JW, et al. Long-term cortisol levels measured in scalp hair of obese patients. Obesity. (2014) 22:1956-8. doi: 10.1002/oby.20795

101. Jackson SE, Kirschbaum C, Steptoe A. Hair cortisol and adiposity in a population-based sample of 2,527 men and women aged 54 to 87 years. Obesity. (2017) 25:539-44. doi: 10.1002/oby.21733

102. Sauve B, Koren G, Walsh G, Tokmakejian S, Van Uum SHM. Measurement of cortisol in human hair as a biomarker of systemic exposure. Clin Invest Med. (2007) 30:E183-E91. doi: 10.25011/cim.v30i5.2894

103. Cummings DE. Endocrine mechanisms mediating remission of diabetes after gastric bypass surgery. Int $J$ Obes. (2009) 33(Suppl 1):S33-40. doi: $10.1038 /$ ijo. 2009.15

104. Rubino F, Forgione A, Cummings DE, Vix M, Gnuli D, Mingrone G, et al. The mechanism of diabetes control after gastrointestinal bypass surgery reveals a role of the proximal small intestine in the pathophysiology of type 2 diabetes. Ann Surg. (2006) 244:741-9. doi: 10.1097/01.sla.0000224726.61448.1b

105. Woods CP, Corrigan M, Gathercole L, Taylor A, Hughes B, Gaoatswe G, et al. Tissue specific regulation of glucocorticoids in severe obesity and the response to significant weight loss following bariatric surgery (BARICORT). J Clin Endocr Metab. (2015) 100:1434-44. doi: 10.1210/jc.20144120

106. Simonyte K, Olsson T, Naslund I, Angelhed JE, Lonn L, Mattsson C, et al. Weight loss after gastric bypass surgery in women is followed by a metabolically favorable decrease in 11 beta-hydroxysteroid dehydrogenase 1 expression in subcutaneous adipose tissue. J Clin Endocr Metab. (2010) 95:3527-31. doi: 10.1210/jc.2009-2472

107. Rask E, Simonyte K, Lonn L, Axelson M. Cortisol metabolism after weight loss: associations with 11 beta-HSD type 1 and markers of obesity in women. Clin Endocrinol. (2013) 78:700-5. doi: 10.1111/j.1365-2265.2012. 04333.x

108. Methlie P, Dankel S, Myhra T, Christensen B, Gjerde J, Fadnes D, et al. Changes in adipose glucocorticoid metabolism before and after bariatric surgery assessed by direct hormone measurements. Obesity. (2013) 21:2495503. doi: 10.1002/oby.20449

109. Diamant S, Shafrir E. Modulation of activity of insulin-dependent enzymes of lipogenesis by glucocorticoids. Eur J Biochem. (1975) 53:541-6. doi: 10.1111/j.1432-1033.1975.tb04097.x

Conflict of Interest: GR has received grant funds from Servier Laboratories and Sun Pharmaceutical Industries Ltd. These funders were not involved in any of the studies discussed here.

The remaining authors declare that the research was conducted in the absence of any commercial or financial relationships that could be construed as a potential conflict of interest.

Copyright $\odot 2020$ Akalestou, Genser and Rutter. This is an open-access article distributed under the terms of the Creative Commons Attribution License (CC BY). The use, distribution or reproduction in other forums is permitted, provided the original author(s) and the copyright owner(s) are credited and that the original publication in this journal is cited, in accordance with accepted academic practice. No use, distribution or reproduction is permitted which does not comply with these terms. 